\title{
An Italian individual-level data study investigating on the association between air pollution exposure and Covid-19 severity in primary-care setting
}

Valeria Pegoraro ( $\square$ valeria.pegoraro@iqvia.com )

IQVIA Solutions Italy S.r.I.

Franca Heiman

IQVIA Solutions Italy S.r.I.

Antonella Levante

IQVIA Solutions Italy S.r.I.

Duccio Urbinati

IQVIA Solutions Italy S.r.I.

Ilaria Peduto

IQVIA Solutions Italy S.r.I.

\section{Research Article}

Keywords: Covid-19, Pneumonia, Air pollution, Particulate matter, Individual-level data, Primary-care

Posted Date: February 26th, 2021

DOl: https://doi.org/10.21203/rs.3.rs-244278/v1

License: (9) This work is licensed under a Creative Commons Attribution 4.0 International License.

Read Full License 


\section{Abstract}

BACKGROUND: Several studies have been focusing on the potential role of atmospheric pollutants in the diffusion and impact on health of Covid-19. This study's objective was to estimate the association between $\leq 10$ micrometers diameter particulate matter $\left(\mathrm{PM}_{10}\right)$ exposure and the likelihood of experiencing pneumonia due to Covid-19 using individual-level data in Italy.

METHODS: Information on Covid-19 patients was retrieved from the Italian IQVIA ${ }^{\circledR}$ Longitudinal Patient Database (LPD), a computerized network of general practitioners (GPs) including anonymous data on patients' consultations and treatments. All patients with a Covid-19 diagnosis during March $18^{\text {th }}, 2020-$ June $30^{\text {th }}, 2020$ were included in the study. The date of first Covid-19 registration was the starting point of the 3-month follow-up (Index Date). Patients were classified based on Covid-19-related pneumonia registrations on the Index date and/or during follow-up presence/absence. Each patient was assigned individual exposure by calculating average $\mathrm{PM}_{10}$ during the 30 -day period preceding the Index Date, and according to GP's office province. A multiple generalized linear mixed model, mixed-effects logistic regression, was used to assess the association between $\mathrm{PM}_{10}$ exposure tertiles and the likelihood of experiencing pneumonia.

RESULTS: Among 6,483 Covid-19 patients included, 1,079 (16.6\%) had a diagnosis of pneumonia. Pneumonia patients were older, more frequently men, more health-impaired, and had a higher individuallevel exposure to $\mathrm{PM}_{10}$ during the month preceding Covid-19 diagnosis. The mixed-effects model showed that patients whose $\mathrm{PM}_{10}$ exposure level fell in the second tertile had a $30 \%$ higher likelihood of having pneumonia than that of first tertile patients, and the risk for those who were in the third tertile was almost doubled.

CONCLUSION: The consistent findings toward a positive association between $\mathrm{PM}_{10}$ levels and the likelihood of experiencing pneumonia due to Covid-19 make the implementation of new strategies to reduce air pollution more and more urgent.

\section{Background}

Covid-19 infection, whose pathogenic agent is Severe Acute Respiratory Syndrome Coronavirus 2 (SARSCoV-2), was firstly reported in Wuhan, Hubei Province, China, in December 2019. (1) The primary target of Covid-19 is the lower airway,(2) and its wide clinical manifestation spectrum includes asymptomatic infection, mild upper respiratory tract symptoms, mild and severe pneumonia, acute respiratory distress syndrome, sepsis and septic shock.(3) Indeed, the course of the disease is often mild and undistinguishable from a common flu, but in a considerable number of cases Covid-19 infection may require hospitalization, and can lead to an acute respiratory distress syndrome (ARDS) and death.(1) Covid-19 outbreak was officially confirmed as a pandemic on 11 February 2020,(4) and since the end of February 2020, contagious has rapidly spread in Italy, particularly in the North (Lombardy, Veneto and Emilia-Romagna), and in many other European countries. As of the end of March, Italy represented the 
third country worldwide in terms of total number of cases and the first one in terms of total number of deaths.(5) As of February 2021, it is estimated that almost 3 million people have contracted Covid-19, and more than 90,000 persons died as a consequence of this infection in Italy. Regions where most of the new cases and deaths are reported are still those of Northern Italy, and particularly Lombardy.(6) A large part of Northern Italy territory includes the Po basin area (Padan Plain), which is the most industrialized area of the country, and one of the most polluted region of Europe.(7) The World Health Organization (WHO), reported that air pollution is responsible for 7 million deaths worldwide every year, and represented one of the main concern regarding public health (8) Airborne particulate matter (PM), which is a heterogeneous mixture of solid and liquid, organic and inorganic material suspended in air, is considered as the most relevant component of air pollution.(9)

A growing body of evidences is showing that some countries were subject to a greater spread of Covid-19 and suffered higher lethality, and this undoubtably captured researchers attention.(10) As a consequence, several studies have been focusing on the potential role of atmospheric pollutants, particularly PM, in the diffusion of Covid-19 both in the short- and the long-term, as well as in the impact of the virus on human health.(4) (10)-(46) One of the ideas underneath the potential relationship between airborne PM and Covid-19 diffusion is that the atmospheric PM might exercise a carrier action along with the virus.(4) (26) Setti and colleagues recently demonstrated the presence of the SARS-CoV-2 RNA on PM.(47) Furthermore, it has been hypothesised that the presence of air-related pollutants can put pressure on the health conditions of the populations at risk, thus offering preconditions for the development of Covid-19 and its complications, including life-threatening ones.(10) Almost all of the studies so far performed succeeded in finding a positive association between air pollution and Covid-19 diffusion and its healthrelated outcomes. However, it is worth mentioning that most of them were ecological studies, thus relied on aggregated data only. Differently, the analysis here reported used patient-level data. In particular, data available from the Italian Regional Environmental Protection Agencies (ARPA) on $\leq 10$ micrometers diameter PM $\left(\mathrm{PM}_{10}\right)$ daily concentrations were collected to assign an individual exposure to a sample of patients experiencing Covid-19 infection. Patients' data on Covid-19 was retrieved from IQVIA ${ }^{\circledR}$ Longitudinal Patient Database (LPD), a large repository of secondary data fed by approximately 900 Italian General Practitioners (GPs).

To authors' knowledge, this was the first study ever using patient-level data aimed at estimating the association between short-term exposure to $\mathrm{PM}_{10}$ and the likelihood of experiencing pneumonia due to Covid-19 infection as a proxy of disease severity on a large sample of patients in Italy.

\section{Methods}

\section{Data sources}

Information on Covid-19 patients was retrieved from the Italian IQVIA® LPD database. Italian IQVIA® LPD is part of a computerized network of GPs from different European countries feeding a centralized database with extensive and anonymous data on patients' consultations and treatments. This database 
reflects the clinical practice of a national sample of GPs since it allows the collection and longitudinal analysis of data taken from patients' records related to prescriptions and healthcare resource utilisations in everyday clinical practice. Drug prescriptions and medical diagnoses are both coded directly by GPs and comply with the Anatomical Therapeutic and Chemical (ATC) classification system, and with the 9th edition of International Classification of Disease (ICD-9-CM), respectively. Currently, about 900 Italian GPs contribute to the IQVIA® LPD, providing data from routinely collected records of $\sim 1.2$ million patients. The Italian IQVIA ${ }^{\circledR}$ database, established in 1998 by the Italian College of General Practitioners (Società Italiana di Medicina Generale - SIMG), was found to be representative of the Italian general population (48)-(50) and a reliable source of information in numerous previous studies for several disease areas. (51)-(57)

$\mathrm{PM}_{10}$ daily concentration data detected by the official air quality monitoring stations located on the entire Italian territory were retrieved from ARPA Regional websites for the period January 2020 - June 2020 and are publicly available.

\section{Study population, exposure and outcomes definitions}

On March 17th, 2020, all the GPs collaborating with the Italian IQVIA® LPD were asked by SIMG/HealthSearch to use two different codes to distinguish between Covid-19 patients with or without pneumonia. The present analysis firstly selected all patients who had at least one Covid-19 registration during the period March 18th, 2020 - June 30th, 2020 (selection period). The date of the first Covid-19 registration was considered as the Index Date and patients were grouped based on the presence/absence of a registration of Covid-19 with pneumonia within 90 days since the Index Date (follow-up) as a proxy of disease severity. The final study cohort was composed of Covid-19 patients who had data availability for the study period and no missing information on age, sex, and $\mathrm{PM}_{10}$ exposure. For each patient included in the analysis, diagnoses recorded during the 12-month period preceding the Index Date (baseline) were collected, and the following conditions, defined through ICD-9 codes, were considered as comorbidities of interest: hypertension (ICD-9 code 401.xx), diabetes (ICD-9 code 250.xx), asthma (ICD-9 code 493.xx), chronic obstructive pulmonary disease (COPD) (ICD-9 codes 490.xx, 491.xx, 492.xx, 494.xx, 495.xx, 496.xx), obesity (ICD-9 codes $278.00,278.01$ and/or a body mass index value of at least 30 $\mathrm{kg} / \mathrm{m}^{2}$ ), coronary artery disease (CAD) (ICD-9 codes 410.xx, 411.xx, 412.xx, 413.xx, 414.xx, V45.81, V45.82), and cerebrovascular disease (ICD-9 codes from 430.xx to 438.xx). Information on age and sex on the Index Date, smoking habits, and GP's office province were also retrieved from the IQVIA® LPD database. The daily average value of $\mathrm{PM}_{10}\left(\mu \mathrm{g} / \mathrm{m}^{3}\right)$ was calculated at province level based on data from ARPA air quality monitoring stations. Individual $\mathrm{PM}_{10}$ exposure was then assigned to each patient by calculating the mean of $\mathrm{PM}_{10}$ daily values observed during the month preceding the Index Date and according to GP's office province.

\section{Statistical Analysis}

A description of patients' individual $\mathrm{PM}_{10}$ exposure was given in terms of mean and standard deviation by Region. Descriptive statistics on patients' characteristics were reported for the two groups of patients 
with or without pneumonia. A stratification of patients by tertiles of $\mathrm{PM}_{10}$ calculated on the overall cohort and presence or absence on pneumonia was also provided. Chi-square tests were performed to investigate on between-groups differences. A multiple generalized linear mixed model, mixed-effects logistic regression, was used to assess the association between $\mathrm{PM}_{10}$ exposure in terms of tertiles and the likelihood of experiencing pneumonia as a consequence of Covid-19 infection. Covariates included in the model were sex, age class, and presence or absence of each comorbidity of interest during baseline period. A random intercept for GP's office province was included in the model to account for potential within-province correlation. Finally, a sensitivity analysis was performed to account for the potential confounding effect of cigarettes smoking on the association between exposure to $\mathrm{PM}_{10}$ and risk of pneumonia. In particular, the above model was run on the subgroup of subjects with smoking habits information available, and a dummy variable indicating whether a patient have ever smoked or not was included. C-statistic was calculated to assess models' discrimination performance (i.e., the extent to which patients who were predicted to be high risk exhibited higher pneumonia rates compared with those who were predicted to be low risk); C-statistic can range from 0.5 (poor discrimination) to 1.0 (perfect discrimination). All the analyses were performed using SAS software, version 9.4 and $p$-values $<0.05$ were considered statistically significant.

\section{Results}

A final cohort of 6,483 patients was defined according to eligibility criteria. Overall, Covid-19 patients without pneumonia numbered 5,404 (83.4\%), while those with pneumonia were 1,079 (16.6\%). Figure 1, which describes individual $\mathrm{PM}_{10}$ exposure by Region, shows that on average, Veneto, Lombardy, Marche, and Campania were the Regions where patients have been exposed to the highest level of $\mathrm{PM}_{10}$ during the month preceding the Index Date. In particular, $\mathrm{PM}_{10}$ mean values ranged from 25.3 to $28.2 \mu \mathrm{g} / \mathrm{m}^{3}$, thus being higher than the mean value calculated on the total cohort $\left(24.1 \mu \mathrm{g} / \mathrm{m}^{3}\right)$. For all the remaining Regions, $\mathrm{PM}_{10}$ mean values fell below the Italian mean value and ranged from $14.0 \mu \mathrm{g} / \mathrm{m}^{3}$ for Valdaosta to $23.1 \mu \mathrm{g} / \mathrm{m}^{3}$ for Emilia-Romagna (Fig. 1). Molise Region was not included in the analysis due to IQVIA® LPD data unavailability.

Table 1 reports Covid-19 patients' characteristics stratified by pneumonia presence or absence. Among Covid-19 patients with pneumonia we found a statistically significant higher proportion of male than the one observed among patients without pneumonia (57.1\% versus $45.9 \%$ ). Overall, mean age of Covid- 19 patients was around 55 years, and subjects with pneumonia were older than those without pneumonia, with mean age being around 64 and 53 years respectively for the two groups (data not shown). Consistently, the proportion of Covid-19 patients aged 65 years or older was $50.4 \%$ and $26.9 \%$ for the group with and without pneumonia, respectively. Ex- and current smokers accounted for a higher proportion among Covid-19 patients without pneumonia. Overall, the most frequently reported comorbidities among those of interest were hypertension, obesity and diabetes mellitus. The comparison between groups showed that among pneumonia patients the proportions of subjects with each condition 
were higher than those observed among patients without pneumonia. All the between-groups differences were statistically significant (Table 1). 
Table 1

- Characteristics of study patients by presence/absence of pneumonia

Total

$(N=6,483)$
COVID-19 without pneumonia

$(\mathrm{N}=5,404)$
COVID-19 with pneumonia

$(\mathrm{N}=1,079)$

Patients characteristics

\section{Gender}

Male: $\mathrm{N}(\%)$

Age classes

$14 \leq$ Age $<45$ years:

$\mathrm{N}(\%)$

$45 \leq$ Age $<55$ years: $\quad 1,387$

$\mathrm{N}(\%)$

$55 \leq$ Age $<65$ years: $\quad 1,316$

$\mathrm{N}(\%)$

$65 \leq$ Age < 75 years: $\quad 963 \quad(14.85 \%) \quad 743$

$\mathrm{N}(\%)$

Age $\geq 75$ years

1,036

$(15.98 \%) \quad 713$

$(13.19 \%)$

$(13.75 \%)$

$(30.94 \%)$

$(22.21 \%)$

$(19.91 \%)$

240

616

$(57.09 \%)$

Smoking status ${ }^{1}$

Never smoked: $\mathrm{N}$

(\%)

Ever smoked: N (\%) 580

$(13.76 \%) \quad 518$

$(14.78 \%)$

62

$(8.73 \%)$

\section{Comorbidities}

\begin{tabular}{llllllll} 
Hypertension: N (\%) & 1,821 & $(28.09 \%)$ & 1,405 & $(26.00 \%)$ & 416 & $(38.55 \%)$ & $<.0001$ \\
\hline Diabetes: N (\%) & 537 & $(8.28 \%)$ & 388 & $(7.18 \%)$ & 149 & $(13.81 \%)$ & $<.0001$ \\
Asthma: N (\%) & 319 & $(4.92 \%)$ & 252 & $(4.66 \%)$ & 67 & $(6.21 \%)$ & 0.0320 \\
Obesity $2: \mathrm{N}(\%)$ & 765 & $(11.80 \%)$ & 594 & $(10.99 \%)$ & 171 & $(15.85 \%)$ & $<.0001$ \\
COPD: N (\%) & 420 & $(6.48 \%)$ & 323 & $(5.98 \%)$ & 97 & $(8.99 \%)$ & 0.0002 \\
CAD: N (\%) & 297 & $(4.58 \%)$ & 220 & $(4.07 \%)$ & 77 & $(7.14 \%)$ & $<.0001$ \\
CVD: N (\%) & 309 & $(4.77 \%)$ & 236 & $(4.37 \%)$ & 73 & $(6.77 \%)$ & 0.0007
\end{tabular}

${ }^{1}$ Calculated on 4,215 subjects with smoking habits available information

${ }^{2}$ Body Mass Index $>30 \mathrm{~kg} / \mathrm{m}^{2}$ or ICD-9 in 278.0x, 278.00, 278.01 


\begin{tabular}{|c|c|c|c|c|c|c|c|}
\hline & \multicolumn{2}{|c|}{$\begin{array}{l}\text { Total } \\
(\mathrm{N}=6,483)\end{array}$} & \multicolumn{2}{|c|}{$\begin{array}{l}\text { COVID-19 without } \\
\text { pneumonia } \\
(\mathrm{N}=5,404)\end{array}$} & \multicolumn{3}{|c|}{$\begin{array}{l}\text { COVID-19 with } \\
\text { pneumonia } \\
(N=1,079)\end{array}$} \\
\hline \multicolumn{8}{|c|}{$\begin{array}{l}\text { Comorbidities } \\
\text { number }\end{array}$} \\
\hline $0: N(\%)$ & 3,664 & $(56.52 \%)$ & 3,200 & $(59.22 \%)$ & 465 & $(43.00 \%)$ & $<.0001$ \\
\hline 1: $\mathrm{N}(\%)$ & 1,652 & $(25.48 \%)$ & 1,340 & $(24.80 \%)$ & 312 & $(28.92 \%)$ & \\
\hline 2: $\mathrm{N}(\%)$ & 791 & $(12.20 \%)$ & 585 & $(10.83 \%)$ & 206 & $(19.09 \%)$ & \\
\hline $3+: \mathrm{N}(\%)$ & 376 & $(5.80 \%)$ & 279 & $(5.16 \%)$ & 97 & $(8.99 \%)$ & \\
\hline \multicolumn{8}{|c|}{${ }^{1}$ Calculated on 4,215 subjects with smoking habits available information } \\
\hline${ }^{2}$ Body $M$ & $\mathrm{~kg} / \mathrm{m}^{2}$ & ICD-9 in 2 & $8.0 x, 2$ & $0,278.01$ & & & \\
\hline
\end{tabular}

The stratification of Covid-19 patients by presence/absence of pneumonia and tertiles of $\mathrm{PM}_{10}$ exposure showed that a much higher proportion of subjects whose mean level of exposure fell in the third tertile was found for pneumonia group. Indeed, almost half of patients with pneumonia had a $\mathrm{PM}_{10}$ mean value higher than $28.7 \mu \mathrm{g} / \mathrm{m}^{3}$ during the month preceding the Index Date, i.e., Covid-19 diagnosis. Differences between the two groups were statistically significant (Fig. 2).

Results from the multiple mixed-effect logistic regression model showed that $\mathrm{PM}_{10}$ exposure level during the month preceding the Index Date was significantly associated with the risk of experiencing pneumonia due to Covid-19 infection. In particular, patients whose level of $\mathrm{PM}_{10}$ exposure fell in the second tertile had a $30 \%$ higher likelihood of having pneumonia than patients whose level of exposure fell into the first tertile; the risk for patients in the third $\mathrm{PM}_{10}$ exposure tertile was almost doubled. Among the covariates included in the model, gender, age class, and presence/absence of baseline asthma and or obesity had an influence on the likelihood of experiencing pneumonia. In particular, male sex, older age, as well as the presence of asthma and/or obesity exposed patients to a higher risk of pneumonia as a consequence of Covid-19 infection. The $\mathrm{C}$-statistic was 0.8 , thus discrimination performance of the model was good (Table 2). 
Table 2

- Estimates from the multiple mixed-effect logistic regression model evaluating the likelihood of experiencing pneumonia

\begin{tabular}{|c|c|c|c|c|c|}
\hline \multirow[t]{2}{*}{ Characteristic } & \multirow[t]{2}{*}{ Category } & \multirow[t]{2}{*}{$\begin{array}{l}\text { Odds } \\
\text { Ratio }\end{array}$} & \multicolumn{3}{|c|}{$\begin{array}{l}\text { 95\% Confidence } \\
\text { Interval }\end{array}$} \\
\hline & & & $\begin{array}{l}\text { Lowe } \\
\text { Limit }\end{array}$ & $\begin{array}{l}\text { Upper } \\
\text { Limit }\end{array}$ & \\
\hline \multirow[t]{3}{*}{$\mathrm{PM}_{10}$ tertiles } & $\mathrm{PM}_{10} \leq 19.84 \mu \mathrm{g} / \mathrm{m}^{3}$ & 1.00 & - & - & \\
\hline & $\begin{array}{l}19.84 \mu \mathrm{g} / \mathrm{m}^{3}<\mathrm{PM}_{10} \leq 28.73 \\
\mu \mathrm{g} / \mathrm{m}^{3}\end{array}$ & 1.34 & 1.09 & 1.65 & * \\
\hline & $\mathrm{PM}_{10}>28.73 \mu \mathrm{g} / \mathrm{m}^{3}$ & 1.93 & 1.55 & 2.39 & * \\
\hline \multirow[t]{2}{*}{ Gender } & Female & 1.00 & - & - & \\
\hline & Male & 1.52 & 1.31 & 1.76 & * \\
\hline \multirow[t]{4}{*}{ Age class } & $14 \leq$ Age < 45 years: $\mathrm{N}(\%)$ & 1.00 & - & - & \\
\hline & $45 \leq$ Age $<55$ years: $\mathrm{N}(\%)$ & 2.25 & 1.74 & 2.91 & * \\
\hline & $55 \leq$ Age $<65$ years: $\mathrm{N}(\%)$ & 3.09 & 2.40 & 3.99 & * \\
\hline & Age $\geq 65$ years & 5.51 & 4.29 & 7.06 & * \\
\hline \multirow[t]{2}{*}{ Hypertension } & No & 1.00 & - & - & \\
\hline & Yes & 0.99 & 0.84 & 1.17 & \\
\hline \multirow[t]{2}{*}{ Diabetes } & No & 1.00 & - & - & \\
\hline & Yes & 1.23 & 0.97 & 1.55 & \\
\hline \multirow[t]{2}{*}{ Asthma } & No & 1.00 & - & - & \\
\hline & Yes & 1.58 & 1.16 & 2.16 & * \\
\hline \multirow[t]{2}{*}{ COPD } & No & 1.00 & - & - & \\
\hline & Yes & 1.02 & 0.78 & 1.34 & \\
\hline \multirow{2}{*}{$\begin{array}{l}\text { Coronary artery } \\
\text { disease }\end{array}$} & No & 1.00 & - & - & \\
\hline & Yes & 0.96 & 0.71 & 1.31 & \\
\hline \multirow{2}{*}{$\begin{array}{l}\text { Cerebrovascular } \\
\text { disease }\end{array}$} & No & 1.00 & - & - & \\
\hline & Yes & 1.01 & 0.75 & 1.37 & \\
\hline
\end{tabular}




\begin{tabular}{|lllll|}
\hline Characteristic & Category & \multicolumn{2}{l|}{$\begin{array}{l}\text { Odds } \\
\text { Ratio }\end{array}$} & \multicolumn{2}{l|}{$\begin{array}{l}95 \% \text { Confidence } \\
\text { Interval }\end{array}$} \\
\hline Obesity & No & 1.00 & - & - \\
\hline & Yes & 1.24 & 1.01 & 1.54 \\
\hline * Statistically significant. P-value $<0.05$. & & & \\
\hline
\end{tabular}

$C=0.77$

Results from the sensitivity analysis run on the subgroup of patients with available information on smoking habits confirmed those from the model run on the total cohort and did not show any association between smoking habits and risk of pneumonia (data not shown).

\section{Discussion}

The main objective of the present study was to understand whether short-term exposure to $\mathrm{PM}_{10}$ may increase Covid-19 patients' likelihood of experiencing pneumonia as a proxy of disease severity. Findings from the multiple mixed-effect logistic model suggest that short-term exposure to $\mathrm{PM}_{10}$ may represent a risk factor for the development of pneumonia in patients with Covid-19 infection. Furthermore, an increasing trend in the likelihood of experiencing pneumonia was observed corresponding to increasing levels of $\mathrm{PM}_{10}$.

Several studies previously investigated on the association between air pollution and Covid-19 spread and adverse outcomes in Italy.(1) (7) (9) (10) (12)-(14) (29) (30) (35) (36) (40) (44) (46) A study by Conticini and colleagues focused on two Northern Italy Regions, Lombardy and Emilia Romagna, which are part of the Padan plain. According to data from Italian Civil Protection, these Regions had the highest level of virus lethality in the world at the time of the first epidemic wave.(6) Being so, Conticini and colleagues speculated that the high level of pollution should be considered as an additional co-factor of the high level of lethality recorded in that area.(1) Dettori and colleagues examined the role of air pollutants in relation to the number of deaths per each Italian province affected by Covid-19. PM $_{10}$ was found to be an independent predictor for Covid-19-related mortality.(10) Similarly, Bianconi et al. investigated on the association between PM exposure and Covid-19 cases and related deaths both at Regional and province level in Italy. Study results seemed to suggest that the greater diffusion and lethality of Covid-19 might be at least partially related to the past and cumulative PM exposure.(9) Accarino and colleagues, who investigated on short-term exposure to atmospheric pollutants and spatio-temporal distribution of Covid19 cases and deaths in Italy, also suggested a potential correlation, particularly with PMs.(35) Coker and colleagues found that a $1 \mu \mathrm{g} / \mathrm{m}^{3}$ increase in long-term exposure to $\mathrm{PM}_{2.5}$ was associated with a $9 \%$ increase in COVID-19 related mortality in Northern Italy.(29) Similar studies have been conducted also in other countries. (17) (20) (23) (25) (27) (30) (33) (34) (36) (38) (39) (41)-(43) (45) A study by Wu and colleagues investigating on the association between $\mathrm{PM}_{2.5}$ exposure and risk of COVID-19 death in the 
United States found that an increase of $1 \mu \mathrm{g} / \mathrm{m}^{3}$ in $\mathrm{PM}_{2.5}$ was associated with an $8 \%$ increase in the COVID-19 death rate.(20) Cole and colleagues found a positive relationship between air pollution and Covid-19 cases, hospital admissions and deaths using data from 355 Dutch municipalities.(23)

Findings from all the above-mentioned analyses came from ecological studies, which used aggregated data. Undoubtably, ecological studies, whose approach is extremely cost-effective, are crucial in rapidly evolving areas of research. Indeed, they allow drawing area level conclusions, which can be useful for policy-making.(58) However, ecological regression analyses are unable to adjust for individual-level risk factors, which, instead, are known to affect Covid-19 health outcomes. To authors' knowledge, very few studies have been performed using individual-level data, and none of them was conducted in Italy.

Travaglio and colleagues investigated on the associations between several air pollutants and the risk of COVID-19 infection using patient-level data obtained from a cohort of 1,450 subjects in the UK. Results from the analysis showed that levels of PM pollutants and nitrogen oxides were associated with an increase in SARS-CoV-2 infections. No investigations were done accounting for Covid-19 severity or mortality.(32) Another study conducted in the UK and using individual-level data found a positive association between exposure to $\mathrm{NO}_{2}$ and Covid-19 mortality, while the association with $\mathrm{PM}_{2.5}$ was uncertain.(31) Finally, a study conducted in Mexico City used patient-level data to estimate the effects of both long- and short-term exposure to $\mathrm{PM}_{2.5}$ on Covid-19 mortality: evidences toward a positive relationship between $\mathrm{PM}_{2.5}$ air pollution and the likelihood for an individual to die following Covid-19 infection did emerge; this relationship increased with age, and, although findings suggested that the association was mainly driven by long-term exposure, authors did not exclude that short-term exposure might also have an effect.(37)

In light of the few studies using patient-level data, authors of the present study do believe that findings here reported should be regarded as extremely significant and add an important contribution in the understanding of the relationship between air pollution and Covid-19 severity. Furthermore, it is worth mentioning that individual-level data in the present study included information on exposure in addition to that on potential confounders. In fact, $\mathrm{PM}_{10}$ exposure was calculated for each patient considering a specific time-window defined based on Covid-19 registration date. Moreover, the inclusion of data from the entire Italian territory and the extension of the study period up to the end of June, allowed to account for a very high variability in terms of exposure. According to authors, the very fact that an association between $\mathrm{PM}_{10}$ level and Covid-19 severity did emerge despite the inclusion of low polluted areas and the lock-down period, which has been shown to have caused a reduction in air pollution levels, (59) might be suggestive of an even stronger association. Besides this, important strengths of the present study, are the representativeness of the data source used to identify Covid-19 cases (49), as well as the setting where data was collected. Indeed, GPs are on the front-line in the management of this pandemic as they are the first point of contact for people affected by Covid-19, except for those patients who develop extremely severe forms of the disease since its onset. As such, we were able to retrieve information on a representative sample of patients in terms of disease severity, and this prevented our study from the risk of selection bias which may have occurred using inpatient-setting data. Risk factors for Covid-19-related

Page $11 / 20$ 
pneumonia other than $\mathrm{PM}_{10}$ exposure identified by the present study were older age, male sex, asthma, and obesity. These findings agree with those from previous studies, with this further confirming the robustness of our data. In particular, Polverino et al. found that 65 years older age and male sex were among predictors of death in a sample of Covid-19 inpatients.(60) Similarly, increasing age was one of the independent risk factors for all-cause in-hospital mortality in a study conducted on 317 hospitalized adult patients with a diagnosis of Covid-19.(61) Baronio and colleagues found that admission to intensive care unit (ICU) and poor survival were associated with advanced age and higher body mass index.(62) Furthermore, obesity was found to be a strong, independent risk factor for respiratory failure, admission to the ICU and death in a sample of 482 Covid-19 hospitalized patients.(63) Finally, a study conducted on behalf of the National Health System (NHS) England linked primary-care electronic medical records of 17,278,392 adults to 10,926 Covid-19-related deaths; among factors associated with Covid-19 death there were male sex, greater age, and severe asthma.(64)

The present study also presents some limits. Firstly, we do not know whether Covid-19 diagnoses were confirmed by a nasopharyngeal swab. However, demographic characteristics of the overall cohort are in line with Covid-19 cases description provided by the Italian Istituto Superiore di Sanità (ISS).

Indeed, according to ISS data, the proportion of men among subjects affected by Covid-19 as of the end of June 2020 was $45.8 \%$, compared to the $47.7 \%$ observed in the present study.

Also, age class distributions were in line, even if patients in the present study were just slightly younger. (65) However, it should be considered that the selection period for the present study was delayed with respect to Covid-19 outbreak, and, differently from sex distribution which remained constant, mean age of Covid-19 patients has progressively decreased.(65) In light of the above consideration, we do believe that IQVIA® LPD is a reliable data source for the identification of Covid-19 cases. Secondly, the main analysis investigating on the association between $\mathrm{PM}_{10}$ exposure and risk of Covid-19-related pneumonia performed on the overall cohort did not account for smoking habits due to the limited availability of such information. However, results from the sensitivity analysis run on the subgroup of patients confirmed all the associations found by the analysis performed on the overall cohort. Furthermore, it is worth mentioning that there were previous studies that did not find a correlation between smoking and adverse outcomes in Covid-19 patients.(66) Thirdly, it is possible that the date of the Covid-19 diagnosis registration did not exactly correspond to the date of infection's onset. However, authors of the present study are confident that the application of a 30-day time-window to estimate average $\mathrm{PM}_{10}$ exposure should have mitigated the potential effect of this limitation.

\section{Conclusion}

This is the first study aimed to investigate on the association between PM10 exposure and the risk of developing Covid-19-related pneumonia as a proxy of disease severity using individual-level data in Italy. Consistent findings toward a positive association between $\mathrm{PM}_{10}$ levels and the likelihood of experiencing pneumonia were found. Authors of the present study would like to claim the urgency of implementing new strategies to reduce air pollution.

Page $12 / 20$ 


\section{Declarations}

\section{Ethics approval and consent to participate}

Studies conducted on IQVIA ${ }^{\circledR}$ LPD data do not require an approval by an Ethical Committee. Indeed, IQVIA ${ }^{\circledR}$ LPD relies on anonymous data which are not originated by any clinical trial. Before being stored into IQVIA databases, data is anonymized through non-identifiable encryption process directly on GPs' computer and patients' names are not collected into IQVIA ${ }^{\circledR}$ LPD. IQVIA ${ }^{\circledR}$ LPD complies with the European Regulation 679/2016 and the ex-Legislative Decree 196/03 and subsequent modifications.

\section{Consent for publication}

Not applicable.

\section{Availability of data and materials}

IQVIA ${ }^{\circledR}$ LPD data that support the findings of this study are available from IQVIA, but restrictions apply to the availability of these data, which were used under license for the current study, and so are not publicly available. Data are, however, available from the corresponding author upon reasonable request and with permission of IQVIA. $\mathrm{PM}_{10}$ daily concentration data detected by the official air quality monitoring stations located on the entire Italian territory were retrieved from ARPA Regional websites for the period January 2020 - June 2020 and are publicly available.

\section{$\underline{\text { Competing interests }}$}

All the authors are employees of IQVIA Solutions Italy S.r.I. The authors declare that they have no competing interests

\section{Funding}

No fundings were received for the conduction of the present study.

\section{$\underline{\text { Authors' contributions }}$}

Valeria Pegoraro, llaria Peduto, Franca Heiman, Antonella Levante and Duccio Urbinati were involved in the conception and design of the study. Valeria Pegoraro and llaria Peduto were involved in data analysis. Valeria Pegoraro was involved in drafting the paper. Valeria Pegoraro, Ilaria Peduto, Franca Heiman, Antonella Levante and Duccio Urbinati were involved in data interpretation, critically reviewed the paper, read, and approved the final manuscript.

\section{Acknowledgements}

Not applicable. 


\section{References}

1. Conticini E, Frediani B, Caro D. Can atmospheric pollution be considered a co-factor in extremely high level of SARS-CoV-2 lethality in Northern Italy? Environ Pollut. 2020 Jun;261:114465.

2. Giacomet V, Stracuzzi M, Paradiso L, Di Cosimo ME, Rubinacci V, Zuccotti G. Defining the clinical phenotype of COVID-19 in children. Pediatr Allergy Immunol. 2020 Nov;31(S26):82-4.

3. Menzella F, Matucci A, Vultaggio A, Barbieri C, Biava M, Scelfo C, et al. COVID-19: general overview, pharmacological options and ventilatory support strategies. Multidiscip Respir Med. 2020 Jan 28;15(1):708.

4. Martelletti L, Martelletti P. Air Pollution and the Novel Covid-19 Disease: a Putative Disease Risk Factor. SN Compr Clin Med. 2020 Apr;2(4):383-7.

5. Ortenzi F, Albanese E, Fadda M. A Transdisciplinary Analysis of COVID-19 in Italy: The Most Affected Country in Europe. Int J Environ Res Public Health. 2020 Dec 18;17(24):9488.

6. Protezione Civile Italiana. Available at: http://www.protezionecivile.gov.it/. Last accessed 14 Feb 2021

7. Filippini T, Rothman KJ, Cocchio S, Narne E, Mantoan D, Saia M, et al. Associations between mortality from COVID-19 in two Italian regions and outdoor air pollution as assessed through tropospheric nitrogen dioxide. Sci Total Environ. 2020 Nov;143355.

8. World Health Organization. Air pollution. Available at: https://www.who.int/health-topics/airpollution. Last accessed 14 Feb 2021

9. Bianconi V, Bronzo P, Banach M, Sahebkar A, Mannarino MR, Pirro M. Particulate matter pollution and the COVID-19 outbreak: results from Italian regions and provinces. Arch Med Sci AMS. 2020;16(5):985-92.

10. Dettori M, Deiana G, Balletto G, Borruso G, Murgante B, Arghittu A, et al. Air pollutants and risk of death due to COVID-19 in Italy. Environ Res. 2021 Jan;192:110459.

11. Li H, Xu X-L, Dai D-W, Huang Z-Y, Ma Z, Guan Y-J. Air pollution and temperature are associated with increased COVID-19 incidence: A time series study. Int J Infect Dis. 2020 Aug;97:278-82.

12. Bontempi E. First data analysis about possible COVID-19 virus airborne diffusion due to air particulate matter (PM): The case of Lombardy (Italy). Environ Res. 2020 Jul;186:109639.

13. Coccia M. Factors determining the diffusion of COVID-19 and suggested strategy to prevent future accelerated viral infectivity similar to COVID. Sci Total Environ. 2020 Aug;729:138474.

14. Fattorini $D$, Regoli F. Role of the chronic air pollution levels in the Covid-19 outbreak risk in Italy. Environ Pollut. 2020 Sep;264:114732.

15. Frontera A, Cianfanelli L, Vlachos K, Landoni G, Cremona G. Severe air pollution links to higher mortality in COVID-19 patients: The "double-hit" hypothesis. J Infect. 2020 Aug;81(2):255-9.

16. Frontera A, Martin C, Vlachos K, Sgubin G. Regional air pollution persistence links to COVID-19 infection zoning. J Infect. 2020 Aug;81(2):318-56. 
17. Liang D, Shi L, Zhao J, Liu P, Schwartz J, Gao S, et al. Urban Air Pollution May Enhance COVID-19 Case-Fatality and Mortality Rates in the United States [Internet]. Occupational and Environmental Health; 2020 May [cited 2021 Jan 7]. Available from: http://medrxiv.org/lookup/doi/10.1101/2020.05.04.20090746

18. Onder G, Rezza G, Brusaferro S. Case-Fatality Rate and Characteristics of Patients Dying in Relation to COVID-19 in Italy. JAMA [Internet]. 2020 Mar 23 [cited 2021 Jan 7]; Available from: https://jamanetwork.com/journals/jama/fullarticle/2763667

19. Riccò M, Ranzieri S, Balzarini F, Bragazzi NL, Corradi M. SARS-CoV-2 infection and air pollutants: Correlation or causation? Sci Total Environ. 2020 Sep;734:139489.

20. Wu X, Nethery RC, Sabath MB, Braun D, Dominici F. Exposure to air pollution and COVID-19 mortality in the United States: A nationwide cross-sectional study [Internet]. Epidemiology; 2020 Apr [cited 2021 Jan 7]. Available from: http://medrxiv.org/lookup/doi/10.1101/2020.04.05.20054502

21. Zoran MA, Savastru RS, Savastru DM, Tautan MN. Assessing the relationship between surface levels of PM2.5 and PM10 particulate matter impact on COVID-19 in Milan, Italy. Sci Total Environ. 2020 Oct; $738: 139825$.

22. Zoran MA, Savastru RS, Savastru DM, Tautan MN. Assessing the relationship between ground levels of ozone (O3) and nitrogen dioxide (NO2) with coronavirus (COVID-19) in Milan, Italy. Sci Total Environ. 2020 Oct; 740:140005.

23. Cole MA, Ozgen C, Strobl E. Air Pollution Exposure and Covid-19 in Dutch Municipalities. Environ Resour Econ. 2020 Aug;76(4):581-610.

24. Magazzino C, Mele M, Schneider N. The relationship between air pollution and COVID-19-related deaths: An application to three French cities. Appl Energy. 2020 Dec;279:115835.

25. Zhu Y, Xie J, Huang F, Cao L. Association between short-term exposure to air pollution and COVID-19 infection: Evidence from China. Sci Total Environ. 2020 Jul;727:138704.

26. Setti L, Passarini F, De Gennaro G, Di Gilio A, Palmisani J, Buono P, et al. Position Paper. Relazione circa l'effetto dell'inquinamento da particolato atmosferico e la diffusione di virus nella popolazione. SIMA - Società Italiana di Medicina Ambientale. Available at: http://www.simaonlus.it/?page_id=694. Last accessed 14 Feb 2021

27. Adhikari A, Yin J. Short-Term Effects of Ambient Ozone, PM2.5, and Meteorological Factors on COVID-19 Confirmed Cases and Deaths in Queens, New York. Int J Environ Res Public Health. 2020 Jun 5;17(11):4047.

28. Andrée BPJ. Incidence of COVID-19 and Connections with Air Pollution Exposure: Evidence from the Netherlands [Internet]. Epidemiology; 2020 May [cited 2021 Jan 7]. Available from: http://medrxiv.org/lookup/doi/10.1101/2020.04.27.20081562

29. Coker ES, Cavalli L, Fabrizi E, Guastella G, Lippo E, Parisi ML, et al. The Effects of Air Pollution on COVID-19 Related Mortality in Northern Italy. Environ Resour Econ. 2020 Aug;76(4):611-34.

30. Pansini R, Fornacca D. Early evidence of a higher incidence of COVID-19 in the air-polluted regions of eight severely affected countries [Internet]. Epidemiology; 2020 May [cited 2021 Jan 7]. Available 
from: http://medrxiv.org/lookup/doi/10.1101/2020.04.30.20086496

31. Konstantinoudis G, Padellini T, Bennett JE, Davies B, Ezzati M, Blangiardo M. Long-term exposure to air-pollution and COVID-19 mortality in England: a hierarchical spatial analysis [Internet]. Public and Global Health; 2020 Aug [cited 2021 Jan 7]. Available from: http://medrxiv.org/lookup/doi/10.1101/2020.08.10.20171421

32. Travaglio M, Yu Y, Popovic R, Selley L, Leal NS, Martins LM. Links between air pollution and COVID19 in England [Internet]. Toxicology; 2020 Apr [cited 2021 Jan 7]. Available from: http://medrxiv.org/lookup/doi/10.1101/2020.04.16.20067405

33. Vasquez-Apestegui V, Parras-Garrido E, Tapia V, Paz-Aparicio VM, Rojas JP, Sánchez-Ccoyllo OR, et al. Association Between Air Pollution in Lima and the High Incidence of COVID-19: Findings from a Post Hoc Analysis [Internet]. In Review; 2020 Jul [cited 2021 Jan 7]. Available from: https://www.researchsquare.com/article/rs-39404/v1

34. Yao Y, Pan J, Liu Z, Meng X, Wang W, Kan H, et al. Temporal association between particulate matter pollution and case fatality rate of COVID-19 in Wuhan. Environ Res. 2020 Oct;189:109941.

35. Accarino G, Lorenzetti S, Aloisio G. Assessing correlations between short-term exposure to atmospheric pollutants and COVID-19 spread in all Italian territorial areas. Environ Pollut. 2021 Jan;268:115714.

36. Ogen Y. Assessing nitrogen dioxide (NO2) levels as a contributing factor to coronavirus (COVID-19) fatality. Sci Total Environ. 2020 Jul 15;726:138605.

37. López-Feldman A, Heres D, Marquez-Padilla F. Air pollution exposure and COVID-19: A look at mortality in Mexico City using individual-level data. Sci Total Environ. 2021 Feb 20;756:143929.

38. Hou C-K, Qin Y-F, Wang G, Liu Q-L, Yang X-Y, Wang H. Impact of a Long-Term Air Pollution Exposure on the Case Fatality Rate of COVID-19 Patients - A Multi-City Study. J Med Virol. 2021 Jan 20;

39. Bilal null, Bashir MF, Komal B, Benghoul M, Bashir MA, Tan D. Nexus Between the COVID-19 Dynamics and Environmental Pollution Indicators in South America. Risk Manag Healthc Policy. 2021;14:67-74.

40. Cascetta E, Henke I, Di Francesco L. The Effects of Air Pollution, Sea Exposure and Altitude on COVID-19 Hospitalization Rates in Italy. Int J Environ Res Public Health. 2021 Jan 8;18(2).

41. Fernández D, Giné-Vázquez I, Liu I, Yucel R, Nai Ruscone M, Morena M, et al. Are environmental pollution and biodiversity levels associated to the spread and mortality of COVID-19? A four-month global analysis. Environ Pollut Barking Essex 1987. 2020 Dec 21;271:116326.

42. Hassan MS, Bhuiyan MAH, Tareq F, Bodrud-Doza M, Tanu SM, Rabbani KA. Relationship between COVID-19 infection rates and air pollution, geo-meteorological, and social parameters. Environ Monit Assess. 2021 Jan 4;193(1):29.

43. Hutter H-P, Poteser M, Moshammer H, Lemmerer $K$, Mayer $M$, Weitensfelder $L$, et al. Air Pollution Is Associated with COVID-19 Incidence and Mortality in Vienna, Austria. Int J Environ Res Public Health. 2020 Dec 11;17(24). 
44. Fiasca F, Minelli M, Maio D, Minelli M, Vergallo I, Necozione S, et al. Associations between COVID-19 Incidence Rates and the Exposure to PM2.5 and NO2: A Nationwide Observational Study in Italy. Int J Environ Res Public Health. 2020 Dec 13;17(24).

45. Hoang T, Nguyen TQ, Tran TTA. Short-term exposure to ambient air pollution in association with COVID-19 of two clusters in South Korea. Trop Med Int Health TM IH. 2020 Dec 15;

46. Rovetta A, Castaldo L. Relationships between Demographic, Geographic, and Environmental Statistics and the Spread of Novel Coronavirus Disease (COVID-19) in Italy. Cureus. 2020 Nov 9;12(11):e11397.

47. Setti L, Passarini F, De Gennaro G, Barbieri P, Perrone MG, Borelli M, et al. SARS-Cov-2RNA found on particulate matter of Bergamo in Northern Italy: First evidence. Environ Res. 2020 Sep;188:109754.

48. Filippi A, Vanuzzo D, Bignamini AA, Sessa E, Brignoli O, Mazzaglia G. Computerized general practice databases provide quick and cost-effective information on the prevalence of angina pectoris. Ital Heart J Off J Ital Fed Cardiol. 2005 Jan;6(1):49-51.

49. XIII Report Health Search (edizione 2020). Istituto di Ricerca della SIMG. Società Italiana di Medicina Generale e delle Cure Primarie. Available at: https://www.healthsearch.it/report/. Last accessed 14 Feb 2021

50. Perera G, Rijnbeek PR, Alexander M, Ansell D, Avillach P, Duarte-Salles T, et al. Vascular and metabolic risk factor differences prior to dementia diagnosis: a multidatabase case-control study using European electronic health records. BMJ Open. 2020 Nov;10(11):e038753.

51. Ravera M, Cannavò R, Noberasco G, Guasconi A, Cabib U, Pieracci L, et al. High performance of a risk calculator that includes renal function in predicting mortality of hypertensive patients in clinical application. J Hypertens. 2014 Jun;32(6):1245-54.

52. Levi M, Rosselli M, Simonetti M, Brignoli O, Cancian M, Masotti A, et al. Epidemiology of iron deficiency anaemia in four European countries: a population-based study in primary care. Eur $\mathrm{J}$ Haematol. 2016 Dec;97(6):583-93.

53. Katz P, Pegoraro V, Liedgens $\mathrm{H}$. Characteristics, resource utilization and safety profile of patients prescribed with neuropathic pain treatments: a real-world evidence study on general practices in Europe - the role of the lidocaine 5\% medicated plaster. Curr Med Res Opin. 2017 Aug;33(8):1481-9.

54. Di Marco F, Santus P, Terraneo S, Peruzzi E, Muscianisi E, Ripellino C, et al. Characteristics of newly diagnosed COPD patients treated with triple inhaled therapy by general practitioners: a real world Italian study. NPJ Prim Care Respir Med. 2017 Sep 7;27(1):51.

55. Agostoni E, Barbanti P, Frediani F, Trifirò G, Burgio L, di Nola L, et al. Real-world insights on the management of migraine patients: an Italian nationwide study. Curr Med Res Opin. 2019;35(9):1545-54.

56. Levi M, Simonetti M, Marconi E, Brignoli O, Cancian M, Masotti A, et al. Gender differences in determinants of iron-deficiency anemia: a population-based study conducted in four European countries. Ann Hematol. 2019 Jul;98(7):1573-82. 
57. Lavorini F, Bianco A, Blasi F, Braido F, Corsico AG, Di Marco F, et al. What drives inhaler prescription for asthma patients? Results from a real-life retrospective analysis. Respir Med. 2020;166:105937.

58. Wu X, Nethery RC, Sabath MB, Braun D, Dominici F. Air pollution and COVID-19 mortality in the United States: Strengths and limitations of an ecological regression analysis. Sci Adv. 2020 Nov;6(45).

59. Vultaggio M, Varrica D, Alaimo MG. Impact on Air Quality of the COVID-19 Lockdown in the Urban Area of Palermo (Italy). Int J Environ Res Public Health. 2020 Oct 9;17(20):7375.

60. Polverino F, Stern DA, Ruocco G, Balestro E, Bassetti M, Candelli M, et al. Comorbidities, Cardiovascular Therapies, and COVID-19 Mortality: A Nationwide, Italian Observational Study (ItaliCO). Front Cardiovasc Med. 2020 Oct 9;7:585866.

61. Vena A, Giacobbe DR, Di Biagio A, Mikulska M, Taramasso L, De Maria A, et al. Clinical characteristics, management and in-hospital mortality of patients with coronavirus disease 2019 in Genoa, Italy. Clin Microbiol Infect. 2020 Nov;26(11):1537-44.

62. Baronio M, Freni-Sterrantino A, Pinelli M, Natalini G, Tonini G, Marri M, et al. Italian SARS-CoV-2 patients in intensive care: towards an identikit for subjects at risk? Eur Rev Med Pharmacol Sci. 2020 Sep;24(18):9698-704.

63. Rottoli M, Bernante P, Belvedere A, Balsamo F, Garelli S, Giannella M, et al. How important is obesity as a risk factor for respiratory failure, intensive care admission and death in hospitalised COVID-19 patients? Results from a single Italian centre. Eur J Endocrinol. 2020 Oct;183(4):389-97.

64. Williamson EJ, Walker AJ, Bhaskaran K, Bacon S, Bates C, Morton CE, et al. Factors associated with COVID-19-related death using OpenSAFELY. Nature. 2020 Aug;584(7821):430-6.

65. Sorveglianza integrata Covid-19: archivio. Epicentro. Istituto Superiore di Sanità. Avaliable at https://www.epicentro.iss.it/coronavirus/sars-cov-2-sorveglianza-dati-archivio. Last accessed 14 Feb 2021

66. Lippi G, Henry BM. Active smoking is not associated with severity of coronavirus disease 2019 (COVID-19). Eur J Intern Med. 2020 May;75:107-8.

\section{Figures}




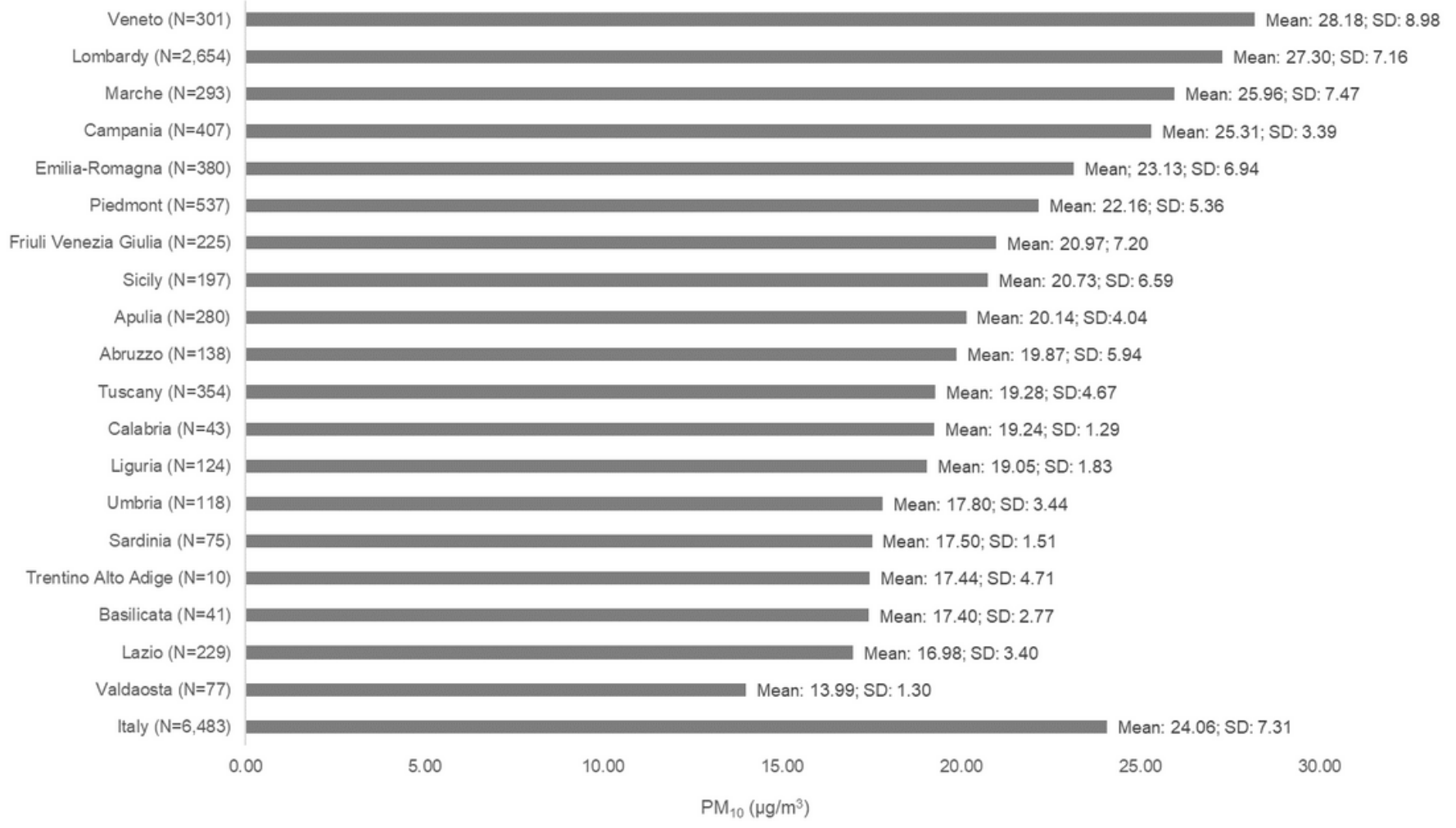

\section{Figure 1}

PM10 $(\mu \mathrm{g} / \mathrm{m} 3)$ - Mean (standard deviation) values calculated based on the average daily values during the month preceding the Index Date for each patient by Region

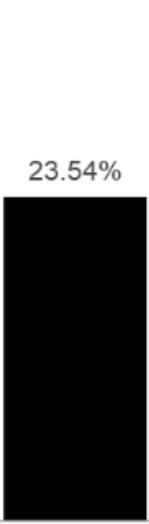

$\mathrm{T} 1(\mathrm{PM} 10 \leq 19.84 \mu \mathrm{g} / \mathrm{m} 3)$

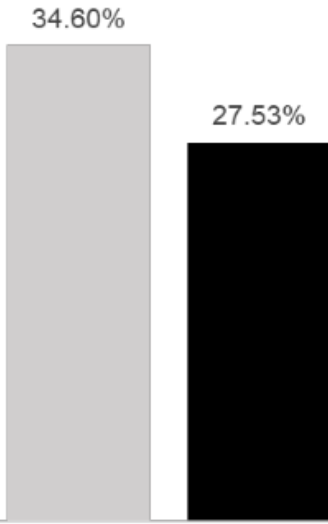

$\mathrm{T} 2(19.84 \mu \mathrm{g} / \mathrm{m} 3<\mathrm{PM} 10 \leq 28.73 \mu \mathrm{g} / \mathrm{m} 3)$
$48.93 \%$

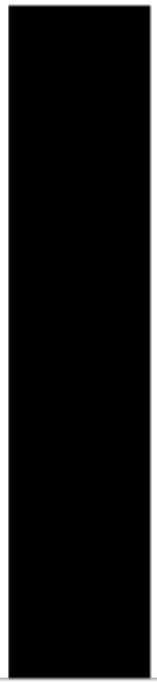

T3 (PM10 > $28.73 \mu \mathrm{g} / \mathrm{m} 3)$ 
Figure 2

COVID-19 patients stratified by presence/absence of pneumonia and tertiles of PM10 exposure during the month preceding the Index Date 